\title{
Staff and student perspectives of online teaching and learning; implications for belonging and engagement at university - a qualitative exploration
}

\author{
Lija Abu, Craig Chipfuwamiti, Adrian-Mihai Costea, Alison Faith Kelly, Krisztina \\ Major, Hilda Mary Mulrooney \\ Kingston University, London, UK
}

\begin{abstract}
A sense of belonging within higher education (HE) enhances educational engagement and attainment. The rapid shift to online provision has implications for reducing students' sense of belonging at university. We have previously shown that students consider belonging in $\mathrm{HE}$ to be important and that their personal sense of belonging was high. We also found that sense of belonging had elements of people and place: relationships with peers and staff were influential and the physical campus facilitated social relationships. In the first lockdown, we showed that sense of belonging in both staff and students at our large wideningparticipation London university was reduced. In this paper, we report on a continuing project to explore the impact of sustained provision of learning online, focusing on qualitative interviews carried out with forty-three students and twenty-three staff. Both groups identified advantages and disadvantages of online provision. Advantages included flexibility and accessibility, with savings - financial and time - owing to reduced commuting. However, both groups identified a negative impact on social relationships, student motivation and engagement. Future development of blended learning should be planned, supported and structured to optimise the benefits.
\end{abstract}

Keywords: blended, online, belonging, social, engagement

\section{Background}

The sudden onset of the COVID-19 pandemic resulted in fundamental changes in how teaching was delivered. In an attempt to flatten the curve and support the social distancing advocated as national policy in most countries, teaching and learning moved online almost overnight in March 2020. From mid-April, an estimated ninety-four per cent of learners enrolled in 200 countries were affected by closures of schools and colleges (UN, 2020). Traditionally, online learning has meant distance learning (Barr and Miller, 2013), characterised as "a distant and reciprocal' relationship between staff and students (Kearsley and Moore, 2012). Previously, it was assumed that online learners tended to be older, intrinsically motivated and juggling other commitments (Hanson et al., 1997). However, even before the pandemic, it appeared that technological advances and globalisation of education resulted in younger and more diverse online learners, who nonetheless had strong academic self-concept, were technologically savvy, willing and able to take part in social interaction and collaborative learning online, and were self-directed (Dabbagh, 2007). However, choosing to study online is one thing - being forced to do so because of a global pandemic is another. From academics' perspectives, there was little time to plan the move online. Aside from concerns about the pedagogic adequacy of education provision and the ability 
and capacity of students to access it, moving away from the physical campus has implications for a sense of belonging at university, which in turn influences engagement, retention and attainment.

In response to the pandemic and to investigate the effects of the shift to online teaching and learning, we carried out a research project in two parts within our institution, Kingston University London: 1) exploring the impact of the abrupt move to online teaching in the first lockdown (Part 1: March 2020) and 2) exploring from both staff and student perspectives the effectiveness of online teaching and learning currently in place (Part 2: continuing). In Part 1, we found that the sense of belonging, for both staff and students, lessened in the first lockdown (Mulrooney and Kelly, 2020a). Why does belonging matter? A sense of belonging is complex and multi-dimensional, encompassing people and place. Ahn and Davies (2019) suggest that it has four components: social engagement, academic engagement, surroundings and personal space. It overlaps with connectedness, a construct which includes students' sense of belonging, integration and satisfaction with their relationship to their institution (Rovai, 2002). We might intuitively expect, if students feel a sense of legitimacy, of fitting in with their institution, of being welcome and having a place, that their level of satisfaction will improve, and as a consequence, our retention figures. Indeed, belonging has been shown to enhance students' engagement and attainment (Hausman et al., 2009; Freeman et al, 2007; Thomas, 2012). However, belonging also matters to staff: those who feel that they fit into their organisation are more likely to develop connections with students (O'Brennan et al., 2017). This, in turn, is likely to boost students' sense of belonging, since establishing relationships with their peers and with academic staff is recognised as part of the social element of belonging (Dwyer, 2017; Ahn and Davis, 2019). Opportunities for contact - within staff groups and between staff and students - also enhance staff work satisfaction (Szromek and Wolniak, 2010). Thus, belonging is intertwined with - and therefore influences - important institutional priorities for both staff and students. Out of necessity, the move to online learning changed the nature of interactions within and between staff and student groups. As part of our continuing work, we want to explore whether the reduced sense of belonging we identified in the first lockdown has since persisted - and if it will carry on for even longer.

Within a large post-92 higher education institution (HEI) with a strong widening participation focus, our student body includes many atypical groups with diverse support needs (e.g., mature or commuting students, those working part-time or with caring responsibilities, careleavers or those first-in-family to higher education (HE) or from diverse ethnic backgrounds). Current internal statistics show that approximately $63 \%$ of our students are from black, Asian and minority ethnic (BAME) groups, 59\% are female, $49 \%$ are mature, 55\% are commuters and $43 \%$ are first-in-family to HE. This presents challenges, since developing a sense of legitimacy and belonging in HE may be more difficult for atypical students (Reay et al., 2010; Wainwright and Marandet, 2010; Waite, 2013; O'Shea, 2015/2016; Southall et al., 2016). Exploring how the move online affects our diverse staff and student groups does matter, since it is likely that a blended-learning approach will be adopted in the future. In addition to belonging, our current work focuses on perceptions of online teaching and learning - what is working well and not so well - so that future plans may be evidence-based.

Traditionally, our teaching has been campus-based and almost entirely face-to-face in mixed-size groups. In a study involving 617 undergraduate respondents and using 
questionnaires to collect qualitative and quantitative data, we previously found that $73 \%$ of participants agreed that a sense of belonging at university was important, while $78 \%$ had a personal sense of belonging. The importance of social aspects was clear: respondents highlighted relationships - with academic staff and with other students - and extra-curricular social activities such as clubs and societies (Kelly and Mulrooney, 2019). Respondents also identified good relationships with academic staff and the feeling that students mattered individually to staff as hallmarks of high quality HE (Dicker et al., 2017, 2018) - this an important consideration in the competitive world of education provision. Rather like Ahn and Davis (2019), we have also found that there is an element of 'place' in belonging: that geographical location affects belonging in Level 3 (foundation) students (Goldring et al., 2018) and that the physical space on campus helps to develop belonging in undergraduate students (Mulrooney and Kelly, 2020b). This is unsurprising, since the nature of the physical space will influence how easily social interactions within and between staff and student groups occur. Given that peer and staff inter-relationships and the physical space on campus so powerfully assist belonging, the suddenness with which the pandemic hit teaching and learning had significant implications.

Our continuing work is a collaboration between undergraduate students at Level 5 and staff; it aims to build upon our previous findings, exploring in what ways and to what degree the changes to teaching and learning methodology altered the sense of belonging of both staff and students, as well as determining the wider educational implications of changes caused by the pandemic. In this paper, only qualitative data from the interviews in Part 2 of the current project are presented, though, for the sake of completeness, we describe below the methodology for the whole project.

\section{Methods:}

Part 1 of the project collected data by means of online questionnaires (this work has been completed and published (Mulrooney and Kelly, 2020a); Part 2 used online questionnaires and optional online interviews, individual or group; this work continues. Ethical approval for both parts of the project was granted by the University's Faculty Research Ethics Committee.

\section{Qualitative data collection: questionnaires}

For both parts of the research, we collected qualitative and quantitative data via questionnaires; optional interviews in Part 2 provided additional qualitative information. We have already described the questionnaires for Part 1 (Mulrooney and Kelly, 2020a). Bespoke questionnaires for Part 2 explored belonging, using 1) a series of statements derived from Yorke (2016) and Ribeira et al. (2017) and 2) levels of agreement with a series of statements on teaching and learning. An open text box allowed for the addition of qualitative information. We constructed questionnaires by means of Microsoft Forms and sent them via institutional email addresses. We are still collecting questionnaire data and thus have, at the time of writing, not yet analysed it.

\section{Qualitative data collection: interviews}

Part 2 of the research project (continuing) has included optional interviews with staff and students willing to participate. Student partners interviewed students and staff partners interviewed staff. We conducted all interviews online on Microsoft Teams and used interview 
guides to ensure consistency. We made audio recordings and took contemporaneous notes. Interviews with staff focused on: how the pandemic had affected their jobs; what they liked most and least about online teaching; and whether and how online working affected their relationships with other staff and students. Student interviews focused on: how the pandemic affected their learning; what they liked most and least about online delivery; whether the mixture of live and pre-recorded materials used affected their study; and whether and how their friendships and social interactions were affected. Staff and students were given the opportunity to add anything else they wished. All interview materials were stored in Box in password-protected files to which only the research team had access, to ensure participant anonymity. This paper describes the findings from the interviews.

\section{Analysis of qualitative data:}

We analysed the interviews using basic thematic analysis, each interview by one researcher; another team member re-analysed a random sample of ten student interviews (23\%) to ensure consistency with the main themes identified. We collated descriptive statistics for the main themes and the number (\%) of responses for each. In addition, we collated basic demographic statistics on interview participants.

\section{Results}

\section{Participants}

Forty-three students and twenty-three staff were interviewed. Table 1 shows demographic details of participants.

Table 1: Demographic characteristics of student participants. Data are expressed as numbers (\%).

\begin{tabular}{|c|c|c|c|c|}
\hline \multicolumn{5}{|c|}{ Interview participants } \\
\hline \multicolumn{5}{|c|}{ Gender } \\
\hline & Male & \multicolumn{3}{|c|}{ Female } \\
\hline Students & $11(25.6)$ & \multicolumn{3}{|c|}{$32(74.4)$} \\
\hline Staff & $13(56.5)$ & \multicolumn{3}{|c|}{$10(43.5)$} \\
\hline & \multicolumn{4}{|c|}{ Ethnicity $^{+}$} \\
\hline & White & Black & Asian & Mixed/other \\
\hline Students & $21(48.8)$ & $8(18.6)$ & $6(14.0)$ & $7(16.3)$ \\
\hline \multirow[t]{3}{*}{ Staff } & $13(56.5)$ & $0(0.0)$ & $(0.0)$ & $10(43.5)$ \\
\hline & \multicolumn{4}{|c|}{ Age (years) } \\
\hline & 18-21 & $22-25$ & $26-29$ & $\geq 30$ \\
\hline \multirow[t]{3}{*}{ Students* $^{*}$} & $16(37.2)$ & $\begin{array}{c}15 \\
(34.9)\end{array}$ & $2(4.7)$ & $10(23.3)$ \\
\hline & \multicolumn{4}{|c|}{ Year of study ${ }^{*}$} \\
\hline & Level 3 & Level 4 & Level 5 & Level 6 \\
\hline Students* & $9(20.9)$ & $9(20.9)$ & $15(34.9)$ & $8(18.6)$ \\
\hline
\end{tabular}

+One student (2.3) preferred not to state ethnicity; ${ }^{*}$ Two students (4.7) were postgraduate. We did not ask staff about age and year of study was not relevant to them. 


\section{Staff interviews}

\section{Impact of the move to online teaching on workload}

Staff described an increase in workload, with several contributory factors. These included increased meetings and emails, learning new tools for online delivery and preparing recorded materials. All of these resulted in longer hours of work and difficulty in separating home and work lives, with negative feelings as a consequence (table 2).

Table 2: Staff experience of the impact of the move to online teaching on workload

\begin{tabular}{|c|c|c|}
\hline Theme & Subthemes & No (\%) \\
\hline $\begin{array}{c}\text { Increased } \\
\text { workload }\end{array}$ & $\begin{array}{c}\text { Emails and meetings } \\
\text { New processes and practices } \\
\text { New tools: intranet, pre-recordings } \\
\text { Emotions }\end{array}$ & $19(82.6)$ \\
\hline Online sessions: cannot cover as much as face-to-face & $\begin{array}{l}\text { Frustration } \\
\text { Uncertainty } \\
\text { Disorientation } \\
\text { Unhappiness }\end{array}$ & $17(73.9)$ \\
\hline & $\begin{array}{c}\text { Capacity to deliver online } \\
\text { Concerns }\end{array}$ & $20(87.0)$ \\
\hline
\end{tabular}

\section{The pros and cons of online teaching: staff perspective}

Many saw the move to blended learning as inevitable. In that sense, the response to the pandemic was described as an opportunity to make changes, with important potential future advantages for both staff and students (table 3). However, this was by no means unanimous and lack of response from students - perceived as lack of engagement - was frequently described. Without non-verbal cues, staff struggled to estimate their effectiveness and student understanding of and interest in the material.

Staff expressed concern about student attainment: because they were unable to see their students and had limited feedback from them, they found it difficult to ascertain exactly how well students understood and engaged with the material:

"We will have to wait and see how they do" [male staff member]

Staff were mindful that students needed to see them online, but the opposite was not true (often for logistical reasons):

"You switch on webcams but no-one else does" [female staff member] 
Table 3: The pros and cons of online teaching from the staff perspective. Frequency expressed as numbers (\%) stated next to each theme.

\begin{tabular}{|c|c|}
\hline Pros & Cons \\
\hline 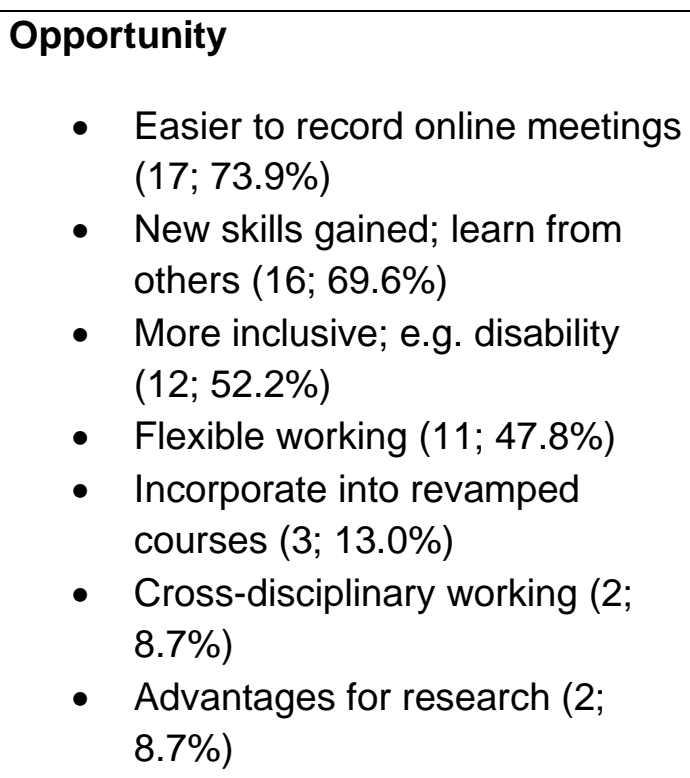 & $\begin{array}{l}\text { Lack of feedback } \\
\begin{array}{l}\text { - No student feedback or interaction; } \\
\text { no cues about pace, degree of } \\
\text { interest or level of understanding } \\
(21 ; 91.3 \%) \\
\text { - Students do not use microphones or } \\
\text { cameras (17;73.9\%) }\end{array}\end{array}$ \\
\hline $\begin{array}{l}\text { Flexibility } \\
\begin{array}{l}\text { - Accessibility to material } \\
\text { increased }(14 ; 60.9 \%)\end{array}\end{array}$ & $\begin{array}{l}\text { Engagement and effectiveness } \\
\begin{array}{l}\text { - } \quad \text { Hard to estimate engagement or } \\
\text { judge student progress }(18 ; 78.3 \%) \\
\text { - Potentially poor attendance owing to } \\
\text { pre-recordings }(15 ; 65.2 \%)\end{array}\end{array}$ \\
\hline \multirow[t]{3}{*}{$\begin{array}{l}\text { Less time wasted } \\
\qquad \quad \text { Travel time reduced }(14 ; 60.9 \%)\end{array}$} & $\begin{array}{l}\text { Static model } \\
\qquad \begin{array}{l}\text { Backwards pedagogic move, } \\
\text { potentially }(10 ; 43.5 \%)\end{array}\end{array}$ \\
\hline & $\begin{array}{l}\text { Lack of facilities } \\
\begin{array}{l}\text { - } \quad \text { IT and technical support }(17 ; 73.9 \%) \\
\text { - } \quad \text { Suitable space/background noise } \\
(11 ; 47.8 \%) \\
\text { - } \quad \text { Family needs }(11 ; 47.8 \%)\end{array}\end{array}$ \\
\hline & $\begin{array}{l}\text { No breaks } \\
\begin{array}{l}\text { - More meetings; back-to-back (12; } \\
52.2 \%)\end{array}\end{array}$ \\
\hline
\end{tabular}




\section{Effect of the move to online teaching on relationship with students and staff: the staff perspective}

Relationships were highlighted as a major concern; in particular, developing and establishing relationships with new students, with possible adverse effects on their learning. With existing students, staff had already formed relationships and could capitalise upon them, but with new students no such relationships existed:

"Some l've never met face-to-face" [male staff member]

Staff had concerns about the mental health of their students. They also felt they had lost creative and networking opportunities with colleagues.

Communications were viewed as far more difficult, with staff having to take responsibility for them since students did not. Emails were seen as a barrier to optimal communications, with potential for misunderstanding.

Table 4: The effect of the move to online teaching on relationship with students and staff: staff perspective. Frequency expressed as numbers (\%) stated next to each theme.

\begin{tabular}{|c|c|}
\hline With students & With staff \\
\hline $\begin{array}{l}\text { Negative impact } \\
\begin{array}{l}\text { - Particular issue with new students } \\
(21 ; 91.3 \%) \\
\text { - Negative impacts on learning (10; } \\
43.5 \%)\end{array}\end{array}$ & $\begin{array}{l}\text { Negative impact } \\
\begin{array}{l}\text { - } \quad \text { Lack of spontaneity and creativity } \\
(11 ; 47.8 \%) \\
\text { - Networking opportunities lost (6; } \\
26.1 \%)\end{array}\end{array}$ \\
\hline $\begin{array}{l}\text { Mental health issues } \\
\text { - Many students with substantial } \\
\text { difficulties; loneliness }(3 ; 13.0 \%)\end{array}$ & $\begin{array}{l}\text { Emails } \\
\qquad \begin{array}{l}\text { - } \quad \text { Barrier to communication; } \\
\text { intrusive }(18 ; 78.3 \%) \\
\text { - } \quad \text { Can be misunderstood }(3 ; 13.0 \%)\end{array}\end{array}$ \\
\hline $\begin{array}{l}\text { Communications } \\
\begin{array}{l}\text { - Have to be managed }(8 ; 34.8 \%) \\
\text { - Much more difficult }(6 ; 26.1 \%)\end{array}\end{array}$ & \\
\hline
\end{tabular}

\section{Student interviews}

Impact of the move to online teaching: the student perspective

A total of fifty-four comments were made, which fell into four main themes, as shown in table 5.

Students described a range of emotions in response to the move to online learning, many of which were associated with anxiety about what would happen and how to navigate new 
systems. Inability to access the physical space of the campus and bespoke learning spaces such as the library was problematic.

"Attending campus motivates learning e.g., after lecture I can use the library for other module work" [Level 6 female student]

"Being in academic environment allows us to perform better" [Level 4 male student]

Additionally, lack of interaction in the online world harmed both learning and social interactions. By contrast, some students recognised potential benefits for the future:

"This year (it's) not just about online learning to gain scientific knowledge...grow your abilities to adapt to situations \& be flexible" [Level 6 female student]

"Makes students more proactive \& lead life independently \& push themselves...they are not the passenger" [female postgraduate student]

Table 5: The impact of online teaching and learning on study: the student perspective. Data are expressed as numbers (\%)

\begin{tabular}{|c|c|}
\hline $\begin{array}{l}\text { Theme (expressed as } \\
\text { numbers (\%) of overall } \\
\text { comments) }\end{array}$ & $\begin{array}{l}\text { Subthemes (expressed as numbers (\%) within } \\
\text { each theme) }\end{array}$ \\
\hline Emotions (10; 18.5\%) & $\begin{array}{l}\text { Confusion (1; 10\%); Anxiety }(1 ; 10 \%) \text {; Guilt (1; } \\
\text { 10\%); Reduced motivation (7; 70\%) }\end{array}$ \\
\hline $\begin{array}{l}\text { Lack of interaction (18; } \\
33.3 \%)\end{array}$ & $\begin{array}{l}\text { No sharing ideas and lack of communications (15; } \\
83.3 \%) \\
\text { Group work not collaborative }(3 ; 16.7 \%)\end{array}$ \\
\hline Physical space (16; 29.6\%) & $\begin{array}{l}\text { Difficulty of being at home } 24 / 7(10 ; 62.5 \%) \\
\text { Loss of library: social and place to learn }(6 ; 37.5 \%)\end{array}$ \\
\hline Can be beneficial $(6 ; 11.1 \%)$ & $\begin{array}{l}\text { Increased independence }(3 ; 50 \%) \text { employability } \\
\text { skills }(3 ; 50 \%)\end{array}$ \\
\hline
\end{tabular}

\section{Pros and cons of the move to online learning: the student perspective}

Like staff, students saw benefits as well as disadvantages of online provision. They valued lecture recordings and the flexibility that these offered in terms of when and how they were accessed and used - especially beneficial for revision. For students with learning difficulties, such as dyslexia, the availability of recorded materials proved to be a significant advantage, allowing for better note-taking and alleviating some of the difficulties faced in standard delivery. Some students said they had more time for study now, while others felt that their studies were adversely affected. 
Online material (both synchronous and asynchronous), was seen as monotonous and less engaging, requiring greater discipline and motivation.

"Too much information \& less explanation compared with face-to-face lectures" [Level 4 female student]

Some students, having to manage their time themselves (something that many were not used to doing, especially if new to university), also found that asynchronous sessions - not timetabled - were difficult to navigate. They also described the lack of interaction with each other as a significant disadvantage to learning and mentioned the difficulty of being unable to ask questions of staff in real time.

"Learning now a lot more individual \& isolated" [female postgraduate student]

"No interaction with teachers to build human relationships" [Level 3 male student]

Students recognised staff efforts to support them, but the online means by which this was done appeared to reduce its value and effectiveness for some:

"You don't know the staff even though they are trying to support you - all online, like robots" [Level 4 female student]

Many students relied on their home environments to learn; these were not always suitable and did not feel like a 'proper' university experience.

"In a lecture theatre I have to be focused because there is nothing around to distract $m e "$ [Level 6 female student]

"At home, procrastination is very high. I've cleaned the ovens, I've cleaned the bins...I've done everything I possibly can to not get on with what I'm supposed to be doing. Motivation has gone out of the window" [Level 6 female student]

By contrast, the learning environment on campus was seen as more motivating, which in turn enhanced learning and attainment. Being online also resulted in less physical movement between classes, less fresh air and more screen time, which some found difficult. 
Table 6: What students like most and least about online learning (online and prerecordings). Data are expressed as numbers and percentages of total responses

\begin{tabular}{|c|c|}
\hline Like most $\left(n=58^{*}\right)$ & Like least $(n=75)$ \\
\hline \multicolumn{2}{|c|}{ Study skills, motivation and accessibility } \\
\hline Recordings helpful for revision $(11 ; 19.0 \%)$ & $\begin{array}{l}\text { Lack of motivation: no interaction, not engaging, } \\
\text { not able to concentrate }(21 ; 33.3 \%)\end{array}$ \\
\hline $\begin{array}{l}\text { Learning is more organised, more independent } \\
(6 ; 10.3 \%)\end{array}$ & $\begin{array}{l}\text { Learn more in hands-on sessions; e.g. labs ( } 6 \text {; } \\
8.0 \%)\end{array}$ \\
\hline $\begin{array}{l}\text { Accessible and flexible - links, speed, timing } \\
(10 ; 17.2 \%)\end{array}$ & $\begin{array}{l}\text { Passive: needs discipline and concentration (2; } \\
2.7 \%)\end{array}$ \\
\hline $\begin{array}{l}\text { Easier to make notes using recordings, } \\
\text { especially with disability }(4 ; 6.9 \%)\end{array}$ & $\begin{array}{l}\text { Stopped coming to lectures as recordings } \\
\text { available }(4 ; 5.3 \%)\end{array}$ \\
\hline \multicolumn{2}{|l|}{$\begin{array}{l}\text { Can structure learning: know what to ask (2; } \\
3.4 \%)\end{array}$} \\
\hline \multicolumn{2}{|l|}{$\begin{array}{l}\text { Important future and employability skills (2; } \\
3.4 \%)\end{array}$} \\
\hline \multicolumn{2}{|c|}{ Learning environment } \\
\hline \multirow[t]{4}{*}{$\begin{array}{l}\text { Studying at home - tranquil, less anxiety ( } 3 \text {; } \\
5.2 \%)\end{array}$} & Miss the library and other resources (10; 13.3\%) \\
\hline & $\begin{array}{l}\text { Studying at home: distracted, monotonous, } \\
\text { mental health impact }(10 ; 13.3 \%)\end{array}$ \\
\hline & No physical activity/fresh air/routine $(4 ; 5.3 \%)$ \\
\hline & More interruptions online $(2 ; 2.7 \%)$ \\
\hline \multicolumn{2}{|c|}{ Social } \\
\hline Synchronous: interaction possible (2; 3.4\%) & No interaction with classmates $(6 ; 8.0 \%)$ \\
\hline Can ask questions: anonymity online (3; 5.2\%) & Asynchronous, cannot ask questions (3; 4.0\%) \\
\hline Staff are more available online (1: $1.7 \%)$ & $\begin{array}{l}\text { Does not feel like 'proper' university experience } \\
(1 ; 1.3 \%)\end{array}$ \\
\hline \multicolumn{2}{|c|}{ Time management } \\
\hline $\begin{array}{l}\text { Save money and time on travel; use for study } \\
(11 ; 19.0 \%)\end{array}$ & $\begin{array}{l}\text { Pre-recordings not timetabled: have to manage } \\
\text { time }(5.3 \%)\end{array}$ \\
\hline & $\begin{array}{l}\text { Increased workload (listening to recordings and } \\
\text { classes) }(2 ; 2.7 \%)\end{array}$ \\
\hline
\end{tabular}

*Additional 3 miscellaneous positive comments 


\section{Effect of online learning on social interactions and friendships: the student perspective}

Online learning had a negative impact on social interactions between students. This was particularly acute for students new to university who did not have existing relationships to fall back on. Those who did found social media useful to help them maintain those relationships, but, even so, they preferred being on campus. The negative impact on relationships related to learning as well as social occasions. Interacting in class, building relationships with peers and getting to know each other were all more difficult. Students found group work harder, since they were unable to ask questions and interact with each other as they would on campus. From the social perspective, although many student societies continued to operate, getting to know each other was harder (table 7).

Table 7: The impact of online learning on student friendships/ social interactions. Data are expressed as numbers and percentages of total responses.

\begin{tabular}{|l|l|l|}
\hline Themes & Subthemes (n=49) & No (\%) \\
\hline Reduced sense of connection & $\begin{array}{l}\text { Harder to connect/ stay in } \\
\text { contact with others; feel } \\
\text { detached, no casual } \\
\text { contacts }\end{array}$ & $23(46.9 \%)$ \\
\hline Building relationships & $\begin{array}{l}\text { Difficult to make friends, } \\
\text { especially if new to } \\
\text { university; easier on } \\
\text { campus }\end{array}$ & $9(18.4 \%)$ \\
\hline Societies & $\begin{array}{l}\text { Societies online, but cannot } \\
\text { easily meet }\end{array}$ & $6(12.2 \%)$ \\
\hline Social media & $\begin{array}{l}\text { Can use social media to } \\
\text { connect with current friends }\end{array}$ & $5(10.2 \%)$ \\
\hline Staff & $\begin{array}{l}\text { Staff supportive, but contact } \\
\text { by email; no interaction with } \\
\text { staff }\end{array}$ & $3(6.1 \%)$ \\
\hline Wack of structure & $\begin{array}{l}\text { Intimidating to ask other } \\
\text { students questions when } \\
\text { you cannot see each other; } \\
\text { group work more difficult }\end{array}$ & $2(4.1 \%)$ \\
\hline & Lack of purpose to the day & $1(2.0 \%)$ \\
\hline
\end{tabular}

\section{Discussion and implications}

Staff and students recognised advantages and disadvantages of online teaching and learning. Students identified online learning as advantageous in several aspects: recordings were flexible and accessible, useful for revision and note-taking; both time and money were saved on travel; and the mixture of synchronous and asynchronous learning helped them 
become more independent. On the other hand, their major concerns included lack of engagement with online learning, loss of university facilities (in particular the library), difficulties with motivation, poor time management and lack of social engagement with others. Staff identified flexibility, accessibility and time saved as advantages of online learning and also saw benefits for cross-disciplinary learning and acquisition of personal skills. However, they expressed a variety of concerns for their students, as well as for themselves and colleagues. Key to these was a perceived lack of student engagement, the difficulties in establishing relationships or enabling students to do so in the online world and the increase in workload, which meant the lines between home and work were frequently blurred. Key themes are discussed below, with illustrative quotes from participants.

\section{Student engagement and social implications of online learning}

Student engagement with online learning was a cause for concern. They tended not to use microphones or cameras and, while this was understandable, the result for staff was a feeling of isolation, even loneliness, very different from the usual teaching experience. It was described as a feeling of "speaking into the void", so that staff felt "like something is always missing". Teaching is essentially a social activity: part of the joy of teaching is being in groups, reading student responses and altering teaching pace or content in response to verbal and visual cues received. Without these, it is difficult for staff to gauge the extent of student understanding or engagement. Previously, little was known about the experience of staff teaching online (Kimmel and Fairchild, 2017). However, feelings of isolation among both students and staff have been described in reflections upon the experience of online teaching (Perrotta and Haeussler Bohan, 2020). In addition, communications online (usually email) were viewed by our respondents as problematic for establishing relationships - aptly described by one participant as the "barriers of distance".

Students, too, found online learning difficult. Some of this was logistical, relating to the structure of synchronous and asynchronous provision within programmes. Much, however, related to the social aspects of learning, for several participants expressed a feeling of isolation. The online environment was seen as a barrier to forming relationships with each other and with staff. Asynchronous learning can result in weaker engagement if students feel disconnected from the group (Serrano et al., 2019), whereas synchronous sessions can increase personal participation and thereby potentially improve cognitive involvement (Hrastinski, 2008). Our students did not distinguish between them, perhaps on account of the unique circumstances this year. Planned provision initially aimed for $30 \%$ on-campus delivery and $70 \%$ online (synchronous plus asynchronous), but all provision moved online because of lockdowns. Being together - forming a community - had social as well as educational value for students and they recognised and valued human contact, which was perceived as less in the online world:

"Staff members \& lecturers make me feel like I belong to the university" [female postgraduate student]

"It's so much nicer to see a face and talk to somebody face-to-face and have that interaction with the lecturer" [Level 6 female student]

Social relationships are not important solely for helping students and staff feel part of the institution, important though that is. Establishment of social presence is intrinsic to the 
'Community of Inquiry' model, espoused by Garrison et al. (1999). Social presence is the extent to which students feel emotionally connected to one another (Kozan and Richardson, 2014) and should go beyond social interactions and relationships to encourage cognitive presence through social interaction (Garrison and Arbaugh, 2007). Given this, the lack of academic motivation that many of our student participants expressed alongside their feelings of social isolation was unsurprising. Establishing a sense of connection in students is essential and possible through collaborative learning groups (Laux et al., 2016). This is clearly easier in a truly blended approach, incorporating face-to-face as well as online learning, in contrast to the approach needed this academic year because of the national restrictions. Interactive learning environments have been shown to predict learner selfregulation, satisfaction and self-efficacy in the e-learning environment (Liaw and Huang, 2013) and socialisation in e-learning has been shown to be increased through use of social media in foreign language acquisition (Asfaranjan et al., 2013). Socialisation is clearly possible with social media and many students choose to use it. However, this is usually a choice made to augment their social experience alongside face-to-face encounters, different from the enforced physical separation currently in place for many.

\section{The learning environment}

Staff and students valued not having to commute to university and appreciated the associated savings in time and money. Simultaneously, both groups highlighted the loss of social interactions, casual conversations and day-to-day communications which build connections, enhance creativity and promote learning. The physical space of the campus was missed, not just for loss of access to learning resources, but for the messages it gave about togetherness and the sense of connection this evoked:

"Doesn't feel like (I) belong less because of not using the facility but being in class together reinforces togetherness and belonging; noises in corridor and students passing by reinforces we are part of a community (ecosystem)" [Level 3 male student]

For many students, the environment at home was not conducive to learning, often because of other distractions; a lack of motivation to study was common.

\section{Flexibility and independence}

Self-paced learning is a major potential advantage of online learning (Serrano et al., 2019), and students themselves recognised the value of recordings which they could access any time, listen to at their own pace and use for note-taking and revision. This academic independence was seen as a current advantage, as well as an employability benefit.

For some groups, e.g., with disability, this flexibility has the potential to reduce stress and increase accessibility to learning by addressing inclusion inequities. (For staff with disability, online working also represented a significant advantage, allowing them to participate in events online that would not have been possible in person.) However, self-paced learning carries responsibilities with it and, for several students, this was a challenge. Asynchronous activities were not timetabled, the onus being on students to prepare for synchronous sessions. This was difficult for many, unused to such responsibility and unprepared for it. It is therefore important that thought is given to the best mechanisms to support students in the transition to blended learning, such that they gain maximum advantage. 


\section{Current situation is not optimal}

Staff recognised that aspects of online teaching were advantageous, but accepted that the current situation is problematic.

"Lots of things are a little bit trickier \& some things are a lot trickier" [male staff member]

The emergency shift to online teaching, at short notice in March 2020, and the lack of certainty about the nature of delivery for September 2020 onwards was very stressful for staff. Although on paper they had the summer to prepare for the new academic year, plans were unclear because of fluctuations in national policy. This resulted in a sense of emergency provision even though it was the start of the new academic year. One participant described it as:

"A plaster on top of it \& hope for the best" [female staff member]

Changes to the University's IT resources, as well as continuing modifications as the systems developed, added further stress. Using what was available, with specialist support lacking, to develop resources (including pre-recorded sessions) was also frustrating for staff, who felt that, despite substantial time preparing, their best was not good enough: member]

"..End result is something passable, not something good-frustrating" [female staff

\section{Implications for the future}

Many institutions are likely to take a blended-learning approach as they move forward (Maguire et al., 2020); future extended lockdowns are possible with the emergence of COVID-19 variants and students will need to catch up (Laurillard, 2021). Indeed, many staff in our study recognised the significant potential of working online, not just for teaching, but for enhancing cross-disciplinary activity and research. However, they were clear that, in moving forward and incorporating blended learning within programmes, planning is key to truly benefiting students.

To be effective, blended learning must achieve a "harmonious balance" between different elements (Garrison and Kanuka, 2004), namely face-to-face delivery, online learning and self-paced learning (Serrano et al., 2019). This is different from what we used this academic year: while blended learning was the intention, the third lockdown meant that all teaching moved online. Our findings must be interpreted in this light. To implement blended learning successfully, clear institutional direction and policy are needed (Garrison and Kanuka, 2004; De Neve et al., 2015), with a strategy, structure (including technological infrastructure) and support for staff in place (Graham et al., 2013). This will require resources: implementation of a blended learning approach poses challenges in terms of the optimal blend, as well as the extra time needed (Serrano et al., 2019). There is the potential to learn from colleagues who are already using blended learning, although best practice may not reflect the realities for all - student needs may be different, just as levels of expertise and support available to staff across institutions are variable. 
Most staff supported the notion of incorporating some elements of online learning into their future delivery although this was not universal. Given the investment that staff and institutions have made in online learning in the last year, it would be a pity to lose it altogether in the future. However, it is important that the benefits are retained while the disadvantages are minimised and this may differ from institution to institution, depending on their staff and student demographics. Identifying what works well should be explored and supported with technology; also required will be time for teams to plan pedagogically sound blended learning. A key issue is the provision of opportunities for interaction (e.g., groupwork), enabling students to develop relationships with each other and with staff within online sessions, in order to enhance their sense of connection to each other and the institution. In addition, it cannot be assumed that all young people are equally technologically savvy and a scaffolded approach will be needed, to support students to develop the selfdirected learning their studies require. There will have to be: clear signposting to activities and resources to support students' learning; explicit expectations about what must be done for each session; and clarity about how the online and in-person sessions map out against the content. Institutions will also have to ascertain how much equipment provision to make in order to support students' blended learning (e.g., laptops, webcams).

Other researchers have shown that varying staff approaches to blended learning derive in part from institutional perspectives (Boelens et al., 2018). It will be interesting to see the extent to which institutions are truly willing to invest in and support effective future blendedlearning provision, but the cost of not doing so is likely to be high.

This is a small study, with a limited dataset, in part because the project is still under way. Of interest is the fact that $35 \%$ of the student participants were from Level 5 , compared with approximately $21 \%$ each from Levels 3 and 4 and $18 \%$ from Level 6 . It appears from our findings that Level 5 students felt more strongly about taking part than other year groups. Level 3 and Level 4 students, being both new to the University, had no other university experience as a comparison. Level 6 students had already established relationships with staff and students and, while the pandemic was severely disruptive for them, they were focused on their own work. Level 5 students, by contrast, had at least one normal year at university before the pandemic to compare with. It is also a year that many of our students find difficult anyway and the imposition of the pandemic made academic life much harder for them. Although the qualitative data identified similar issues across all year groups, analysis of the quantitative data on completion of the project will allow us to explore whether significant differences between the years of study exist.

\section{Reference list}

Ahn, M.Y. and Davis, H.H. (2019) 'Four domains of students' sense of belonging to university.' Studies in Higher Education, 45(3), 622-634. Available at:

https://education.virginia.edu/sites/default/files/DEl/Four\%20domains\%20of\%20students\%2 0sense\%20 of\%20belonging\%20to\%20university.pdf (Accessed: 07 June 2021). 
Asfaranjan, Y.S., Shirzad, F., Baradari, F., Salimi, M. and Salehi, M. (2013) 'Alleviating the senses of isolation and alienation in the virtual world: Socialization in distance education.' Procedia - Social and Behavioral Sciences, 93, 332-337. Available at:

https://www.sciencedirect.com/science/article/pii/S1877042813033028 (Accessed: 07 June 2021).

Barr, B.A. and Miller, S.F. (2013) Higher Education: The Online Teaching and Learning Experience. Phoenix, AZ: University of Phoenix Faculty School of Advanced Studies. Available at: https://files.eric.ed.gov/fulltext/ED543912.pdf (Accessed: 07 June 2021).

Boelens, R., Voet, M. and De Wever, B. (2018) 'The design of blended learning in response to student diversity in higher education: Instructors' views and use of differentiated instruction in blended learning.' Computers \& Education, 120, 197-212. Available at: https://www.researchgate.net/publication/323055082 The design of blended learning in $r$ esponse to student diversity in higher education Instructors' views and use of differen tiated instruction in blended learning (Accessed: 07 June 2021).

Dabbagh, N. (2007) 'The online learner: Characteristics and pedagogical implications.' Contemporary Issues in Technology and Teacher Education, 7(3), 217-226. Available at: https://citejournal.org/wp-content/uploads/2014/05/v7i3general1.pdf (Accessed: 07 June 2021).

De Neve, D., Devos, G. and Tuytens, M. (2015) 'The importance of job resources and selfefficacy for beginning teachers' professional learning in differentiated instruction.' Teaching and Teacher Education, 47, 30-41. Available at:

https://reader.elsevier.com/reader/sd/pii/S0742051X14001541?token=23E76A5583F343200 B175DB0D5E120635AB1867A88E8DACD9DAFD5714DEF240DC5F18C28AF0F5612AD54 13A449CC605E\&originRegion=eu-west-1 \&originCreation=20210609120304 (Accessed: 07 June 2021).

Dicker, R., Garcia, M., Kelly, A., Modabber, P., O'Farrell, A., Pond, A., Pond, N. and Mulrooney, H.M. (2017) 'Student perceptions of quality in higher education: effect of year of study, gender and ethnicity.' New Directions in the Teaching of Physical Sciences, 12(1). Available at: https://journals.le.ac.uk/ojs1/index.php/new-directions/article/view/2332/2273 (Accessed: 07 June 2021).

Dicker, R., Garcia, M., Kelly, A. and Mulrooney, H. (2018) 'What does quality in higher education mean? Perceptions of staff, students and employers.' Studies in Higher Education, 44(8), 1425-1441. Available at:

https://eprints.kingston.ac.uk/id/eprint/40901/1/Mulrooney-H-40901-AAM.pdf (Accessed: 07 June 2021).

Dwyer, T. (2017) 'Persistence in Higher Education through Student-Faculty Interactions in the Classroom of a Commuter Institution.' Innovations in Education and Teaching International, 54(4), 325-334. Available at:

https://www.researchgate.net/publication/284217315 Persistence in higher education thro ugh student-faculty interactions in the classroom of a commuter institution (Accessed: 07 June 2021). 
Freeman, T., Anderman, L. and Jensen, J. (2007) 'Sense of Belonging in College Freshmen at the Classroom and Campus Levels.' The Journal of Experimental Education, 75(3), 203220. Available at:

https://www.researchgate.net/publication/254346913 Sense of Belonging in College Fres hmen at the Classroom and Campus Levels (Accessed: 07 June 2021).

Garrison, D.R. and Kanuka, H. (2004) 'Blended learning: Uncovering its transformative potential in higher education.' The Internet and Higher Education, 7(2), 95-105. Available at: https://www.researchgate.net/publication/222863721 Blended Learning Uncovering Its $\mathrm{Tr}$ ansformative Potential in Higher Education (Accessed: 07 June 2021).

Garrison, D.R., Anderson, T. and Archer, W. (1999) 'Critical inquiry in a text-based environment: Computer conferencing in higher education.' The Internet and Higher Education, 2(2), 87-105. Available at:

https://www.researchgate.net/publication/222474115 Critical Inquiry in a TextBased Environment Computer Conferencing in Higher Education (Accessed: 07 June 2021).

Garrison, D.R. and Arbaugh, J.B. (2007) 'Researching the community of inquiry framework: review, issues, and future directions.' The Internet and Higher Education, 10(3), 157-172. Available at:

http://reinventnet.org/moodle/pluginfile.php/1196/mod resource/content/3/COlreview.pdf (Accessed: 07 June 2021).

Goldring, T., Harper, E., Jassal, R., Joseph, L., Kelly, A., Mulrooney, H., Piper, I. and Walker, H. (2018) 'Experience and expectations of transition to higher education: a qualitative exploration.' New Directions in the Teaching of Physical Sciences, 13(1). Available at: https://journals.le.ac.uk/ojs1/index.php/new-directions/article/view/2849/2659 (Accessed: 07 June 2021).

Graham, C.R., Woodfield, W. and Harris, J.B. (2013) 'A framework for institutional adoption and implementation of blended learning in higher education.' Internet and Higher Education, 18, 4-14. Available at: https://blendedtoolkit.wisc.edu/wpcontent/uploads/2015/03/Framework-for-Institutional-Adoption-and-Implementation-ofBlended-Learning-in-Higher-Education.pdf (Accessed: 07 June 2021).

Hanson, D., Maushak, N.J., Schlosser, C. A., Anderson, M. L., Sorensen, C. and Simonson, M. (1997) Distance Education: Review of the Literature (second edition). Bloomington, Indiana: Association for Educational Communications and Technology. ISBN: 9780892401062

Hausmann, L.R., Ye, F., Schofield, J.W. and Woods, R.L. (2009) 'Sense of belonging and persistence in white and African American first-year students.' Research in Higher Education, 50, 649-669. Available at: https://uploadsssl.webflow.com/59faaf5b01b9500001e95457/5bc55a0236f9e465d23c7377 Hausmann\%2 C\%20L.\%20R.\%2C\%20Ye\%2C\%20F.\%2C\%20Schofield\%2C\%20J.\%20W.\%2C\%20\%26\% 20Woods\%2C\%20R.\%20L.\%202009.pdf (Accessed: 07 June 2021).

Hrastinski, S. (2008) 'The potential of synchronous communication to enhance participation in online discussions: A case study of two e-learning courses.' Information and Management, 
45, 499-506. Available at: https://isiarticles.com/bundles/Article/pre/pdf/17193.pdf

(Accessed: 07 June 2021).

Kearsley, G. and Moore, M. (2012) Distance education: A systems view of online learning. Belmont, Ca: Wadsworth Publishing Co. ISBN: 978-1-111-52099-1

Kelly, A.F. and Mulrooney, H.M. (2019) 'Student perceptions of belonging at university: a qualitative perspective.' New Directions in the Teaching of Physical Sciences, 14(1). Available at: https://journals.le.ac.uk/ojs1/index.php/new-directions/article/view/3238 (Accessed: 07 June 2021).

Kimmel, K.M. and Fairchild, J.L. (2017) 'A full-time dilemma: Examining the experiences of part-time faculty.' The Journal of Effective Teaching, 17(1), 52-65. Available at: https://files.eric.ed.gov/fulltext/EJ1139922.pdf (Accessed: 07 June 2021).

Kozan, K. and Richardson, J.C. (2014) 'Interrelationships between and among social, teaching, and cognitive presence.' Internet and Higher Education, 21, 68-73. Available at: https://daneshyari.com/article/preview/357758.pdf (Accessed: 07 June 2021).

Laurillard, D. (2021) 'How can we support teachers to handle their students' catch-up? Support from an online source.' HEPI Guest Post, 15 February 2021. Available at: https://www.hepi.ac.uk/2021/02/15/how-can-we-support-teachers-to-handle-their-studentscatch-up-and-new-distancing-rules/ (Accessed: 07 June 2021).

Laux, D., Luse, A. and Mennecke, B.E. (2016) 'Collaboration, connectedness, and community: An examination of the factors influencing student persistence in virtual communities.' Computers in Human Behavior, 57, 452-464. Available at:

https://www.researchgate.net/publication/290511031 Collaboration connectedness and co mmunity An examination of the factors influencing student persistence in virtual com munities (Accessed: 07 June 2021).

Liaw, S-S. and Huang, H-M. (2013) 'Perceived satisfaction, perceived usefulness and interactive learning environments as predictors to self-regulation in e-learning environments.' Computers \& Education, 60, 14-24. Available at:

https://www.sciencedirect.com/science/article/abs/pii/S0360131512001765?via\%3Dihub (Accessed: 07 June 2021).

Maguire, D., Dale, L. and Pauli, M. (2020). Learning and teaching reimagined; a new dawn for higher education? Bristol: Jisc. Available at: https://www.jisc.ac.uk/reports/learning-andteaching-reimagined-a-new-dawn-for-higher-education (Accessed: 07 June 2021).

Mulrooney, H.M. and Kelly, A.F. (2020a) 'COVID-19 and the move to online teaching: impact on perceptions of belonging in staff and students in a UK widening participation university.' Journal of Applied Learning and Teaching, 3(2). Available at: https://journals.sfu.ca/jalt/index.php/jalt/article/view/277/255 (Accessed: 07 June 2021).

Mulrooney, H.M. and Kelly, A.K. (2020b) 'The university campus and a sense of belonging: what do students think?' New Directions in the Teaching of Physical Sciences, 15(1). Available at: https://journals.le.ac.uk/ojs1/index.php/new-directions/article/view/3590/3252 (Accessed: 07 June 2021). 
O’Brennan, L., Pas, E. and Bradshaw, C. (2017) 'Multilevel examination of burnout among high school staff: Importance of staff and school factors.' School Psychology Review, 46(2), 165-176. Available at: https://files.eric.ed.gov/fulltext/EJ1156208.pdf (Accessed: 07 June 2021).

O'Shea, S.E. (2015) 'Filling up silences - first in family students, capital and university talk in the home.' International Journal of Lifelong Education, 34(2), 1-17. Available at:

https://www.researchgate.net/publication/272686830 Filling up silences -

first in family students capital and university talk in the home (Accessed: 07 June 2021).

O'Shea, S. (2016) 'First-in-family learners and higher education: Negotiating the 'silences' of university transition and participation.' HERDSA Review of Higher Education, 3, 5-23.

Available at: file:///C:/Users/ku48101/Downloads/HERDSARHE2016v03p05 0.pdf (accessed: 07 June 2021).

Perrotta, K. and Haeussler Bohan, C. (2020) 'A Reflective Study of Online Faculty Teaching Experiences in Higher Education.' Journal of Effective Teaching in Higher Education, 3(1), 50-66. Available at: https://jethe.org/index.php/jethe/article/view/9/30 (Accessed: 07 June 2021).

Reay, D., Crozier, G. and Clayton, J. (2010) 'Fitting in or standing out: working-class students in UK higher education.' British Educational Research Journal, 36(1), 107-124. Available at: https://berajournals.onlinelibrary.wiley.com/doi/epdf/10.1080/01411920902878925 (Accessed: 07 June 2021).

Ribera, A.K., Miller, A.L. and Dumford, A.D. (2017) 'Sense of Peer Belonging and Institutional Acceptance in the First Year: The Role of High-Impact Practices.' Journal of College Student Development, 58(4), 545-563. Available at:

https://www.researchgate.net/profile/Amy-

Ribera/publication/273632010 Sense of Peer Belonging and Institutional Acceptance in the First Year The Role of High-

Impact Practices/links/550713c10cf2d7a28122dca5/Sense-of-Peer-Belonging-andInstitutional-Acceptance-in-the-First-Year-The-Role-of-High-Impact-Practices.pdf (Accessed: 07 June 2021).

Rovai, A. (2002) 'Sense of community, perceived cognitive learning, and persistence in asynchronous learning networks.' Internet and Higher Education, 5(4), 319-332. Available at: https://citeseerx.ist.psu.edu/viewdoc/download?doi=10.1.1.1041.196\&rep=rep1\&type=pdf (Accessed: 07 June 2021).

Serrano, D.R., Auxiliadora Dea-Ayuela, M., Gonzalez-Burgos, E., Serrano-Gil, A. and Lalatsa, A. (2019) 'Technology-enhanced learning in higher education: How to enhance student engagement through blended learning'. European Journal of Education 54, 273-286. Available at: https://doi.org/10.1111/ejed.12330 (Accessed: 07 June 2021). 
Southall, J., Wason, H. and Avery, A. (2016) 'Non-traditional, commuter students and their transition to Higher Education - a synthesis of recent literature to enhance understanding of their needs.' Student Engagement and Experience Journal, 5(1), 1-15. Available at:

https://eprints.kingston.ac.uk/id/eprint/34742/1/Southall-J-34742-VoR.pdf (Accessed: 07 June 2021).

Szromek, A.R. and Wolniak, R. (2020) 'Job Satisfaction and Problems among Academic Staff in Higher Education.' Sustainability, 12(12), 4865. Available at:

https://doi.org/10.3390/su12124865 (Accessed: 07 June 2021).

Thomas, L. (2012) Building Student Engagement and belonging in Higher Education at a time of change. Final report from the What Works? Student Retention and Success

programme. York: HEA. Available at: https://s3.eu-west-

2.amazonaws.com/assets.creode.advancehe-document-

manager/documents/hea/private/what works final report 1568036657.pdf (Accessed: 07 June 2021).

United Nations (2020) Education during COVID-19 and beyond. Policy Briefing. United Nations Sustainable Development Group. Available at:

https://unsdg.un.org/sites/default/files/2020-08/sg policy brief covid-

19 and education august 2020.pdf (Accessed: 07 June 2021).

Wainwright, E. and Marandet, E. (2010) 'Parents in higher education: impacts of university learning on the self and the family.' Educational Review, 62(4), 449-465. Available at:

https://www.tandfonline.com/doi/pdf/10.1080/00131911.2010.487643?casa token=fbu8kzE PdZMAAAAA:XjxA0 jCiThTedwbnKltu2S-6JByPi8-zxT1DnKdDIwH2ko8k-T6jtKsGrpilxcf-XEYKg3koiD (Accessed: 07 June 2021).

Waite, S. (2013) 'Knowing your place in the world: how place and culture support and obstruct educational aims.' Cambridge Journal of Education, 43(4), 413-433. Available at: https://www.tandfonline.com/doi/pdf/10.1080/0305764X.2013.792787?needAccess=true (Accessed: 07 June 2021).

Yorke, M. (2016) 'The development and initial use of a survey of student belongingness engagement and self-confidence in UK higher education.' Assessment and Evaluation in Higher Education, 41(1), 154-166. Available at:

https://www.tandfonline.com/doi/pdf/10.1080/02602938.2014.990415?needAccess=true (Accessed: 07 June 2021). 